\title{
Statistical Methods for Construction Delay Analysis
}

\author{
Ashwini Arun Salunkhe ${ }^{1}$, Rahul S. Patil ${ }^{2}$ \\ ${ }^{I}$ Post Graduate Student, Department of Civil Engineering, Padmashree Dr. D. Y.Patil Institute of Engineering \& \\ Technology. Pimpri, Pune (M.S.) \\ ${ }^{2}$ Assistant Professor, Department of Civil Engineering, Padmashree Dr. D.Y.Patil Institute of Engineering \& \\ Technology. Pimpri, Pune (M.S.)
}

\begin{abstract}
The occurrence of delay is common in most construction projects, due to various reasons and causes before or during construction phase. As the delay impact on time and cost overrun, analyzing of these delay(s) makes easy to give responsibility to concern party. This helps to avoid or minimize delays in future work. Numerous analytical methods are available for analyzing these impacts and selection of proper method depends upon: statistical data available, time available, limitation of method and money available for analyzing. However, information of activities which are responsible for project delay and their magnitude provides the baseline for investing the cause and assessing the responsibility for project delay. This paper reviews research methodology suggested for assessing construction delay factors by analytical methods as well as with the help of computerized schedule analysis methods. The purpose of this study is to review various analytical \& computerized schedule analysis methods for analysis of construction delay factor.
\end{abstract}

Keywords: Analytical methods, Construction, CPM, Delay, Schedule.

\section{INTRODUCTION}

The delay analysis involves not only calculation of delay time but also identification of causes. Therefore, such an analysis becomes a basis for financial calculations which determines the penalties or other damages that shall be assigned to the parties responsible for delay. Schedule delays must be analyzed so that to appoint responsibility for the duration of the delay among the project parties (owner, contractor, and/or third party). There are various method exists for analysis of delay in project activities or project schedule. However, different analysis methods will provide different results for the same circumstances depending on the time and resources available for the analysis and accessibility of project documentation.

Analysis of construction project delay has become a common practice in project life cycle . There are numerous methods and computerized analysis methods available in construction management literature, which are considered for assessing the impact of project delays due to various factors. These methods could certainly provide an impact of delay on project performance. The assessment of this performance in terms of delay becomes valuable for both parties for litigation and responsibility. It is helpful in calculating the damages and penalties as well as the amount of time party has been impacted.

\section{IMPORTANCE OF THE STUDY}

Several factors cause the overall delay in the construction project within contractor's liability and owner's liability. It is mostly seen that delay problems are cause of dispute, negotiation, lawsuit, total desertion, litigation and abandonment. The parties included in contract through claims agree on the additional capital and extra time linked with construction delay. The consequences of delay are different for different parties [8].

The common results of delay are late completion of project, increased cost, and low quality of work, loss of productivity, third party claims, conflicts abandonment or termination of contract. When projects are delayed, the extension of project completion time invite to the additional cost. This results in conflicts between parties (owner, contractor and/or third party), in regards' to file claims for extra compensation or extra time to complete a project. To recover the damages caused by delays, the parties responsible for the occurrence should be identified. Most of the time more than one party is responsible for project delay therefore multiple delays may occur concurrently. Hence, it is important to study \& analyze causes of construction delay, as the services provided by infrastructure projects serve input for other sectors and cost overrun in these project lead to an increase in capital output ratio for the entire economy.

\section{LITERATURE REVIEW}

Bubshait et al. (1998), compared three delay analysis methodologies, those are As-planned schedule delay analysis, As-built schedule analysis and Modified As-built schedule delay analysis. Also, an analysis 
through critical path method (CPM) performed on genuine construction activities. These procedures used to measure schedule delay impact on construction progress. The results of this study conclude that only one method may not be used universally over another in all situations.

Tommy, Fung and Tung (2006) studied the construction delays in Hong Kong. They distributed the questionnaire to 272 civil construction practitioners in Hong Kong, and calculated mean score (MS) for each cause of delay. The result of survey showed six out of ten of most significant causes of construction delay (unforeseen ground conditions, poor site management and supervision, client variation, inexperienced contractor, low speed in co-ordination and seeking approval of concern authorities, inadequate contractor resources).

According to Aibinu and Odeyinka (2006), there is no difference among the different delay factors and none singly contribute to a large percentage of the problem. In this research analysis of quantitative data from completed projects from that 44 factors were identified and contributed to overall delays, in which Pareto analysis revealed that $88 \%$ of the factors were responsible for $90 \%$ of the overall delays.

Finke (1999) paper showed how critical path method schedules can be employed in structured and consistent manner to resolve compensable delay issues. According to study the window analysis technique is most realistic and most reasonable accurate option. Compensable delay analyses, determine the recoverable cost of delay by a contractor [2].

Kim et al. (2005), used a new methodology for delay analysis called "delay analysis method using delay section" (DAMUDS). This method is based on critical path method (CPM) and contemporaneous period analysis (CPA). The paper shows an analysis through three delay analysis methods, that are "what if" method, "but for" method and CPA method. It provides more specific results in analyzing and apportioning schedule delays as compare to CPM and CPA.

Jonathan et al. (2001), invented a method for computing activity delays which uses set of equations and these equations are easily coded into a computer program. The method gives advantage of speedy access of project delay information and activity contribution. The method also provides objective base for assessing responsibilities of delays. For further improvement and automation in construction delays, the method can be integrated to any system.

Hegazy T. and Zhang K (2005), introduced a modified window approach computerized with daily assessment of delays to produce accurate and repeatable results. The proposed approach analyzes the day by day fluctuation in critical path along project duration. The proposed approach is workable for small and medium size projects being implemented on a spreadsheet.

IV. Analytical Methods

Table 1- Analytical Expression used for various studies reported in literature

\begin{tabular}{|c|c|c|c|c|}
\hline $\begin{array}{l}\text { Analysis } \\
\text { methodology }\end{array}$ & Analytical formula & Parameters & Reference & $\begin{array}{l}\text { Research } \\
\text { Methodology }\end{array}$ \\
\hline $\begin{array}{l}\text { Importance Index } \\
\text { (I) }\end{array}$ & $\mathrm{I}=\sum_{i=1}^{4} \frac{\mathrm{a}_{\mathrm{i}} \mathrm{x}_{\mathrm{i}}}{3}$ & $\begin{array}{l}\text { Where, } I=\text { importance index; ai }= \\
\text { constant expressing the weight of the } i \text { th } \\
\text { response, } x i=\text { frequency of the } i \text { th } \\
\text { response given as a percentage of the } \\
\text { total response for each cause; } i= \\
\text { response category index. }\end{array}$ & \multirow[t]{2}{*}{ Assaf et.al. 1995} & \multirow[t]{2}{*}{$\begin{array}{l}\text { Through } \\
\text { questionnaire } \\
\text { survey }\end{array}$} \\
\hline $\begin{array}{l}\text { Rank Correlation } \\
\text { coefficient }(\rho)\end{array}$ & $\rho=\frac{1-6 \sum D^{2}}{N\left(N^{2}-1\right)}$ & $\begin{array}{l}\text { Where, } \mathrm{D}=\text { difference between ranks } \\
\text { given by one party and the rank given by } \\
\text { another party for an individual cause and } \\
\mathrm{N}=\text { Number of cause }\end{array}$ & & \\
\hline $\begin{array}{l}\text { Relative } \\
\text { importance index } \\
\text { (RII) }\end{array}$ & $R I I=\frac{\sum w}{A \times N}$ & $\begin{array}{l}\text { where } \mathrm{w}=\text { weighting given to each factor } \\
\text { by the respondents and ranges from } 1 \text { to } \\
5 \text { where ' } 1 \text { ' is 'not significant' and ' } 5 \text { ' is } \\
\text { 'extremely significant', } \mathrm{A}=\text { highest } \\
\text { weight (i.e. } 5 \text { in this case), and } \mathrm{N}=\text { total } \\
\text { number of respondents. }\end{array}$ & $\begin{array}{l}\text { Ramanathan, } \\
\text { et al. (2012) }\end{array}$ & $\begin{array}{l}\text { Through } \\
\text { questionnaire } \\
\text { survey }\end{array}$ \\
\hline
\end{tabular}


Statistical Methods for Construction Delay Analysis

\begin{tabular}{|c|c|c|c|c|}
\hline $\begin{array}{l}\text { Analysis } \\
\text { methodology }\end{array}$ & $\begin{array}{l}\text { Analytical } \\
\text { formula }\end{array}$ & Parameters & Reference & $\begin{array}{l}\text { Research } \\
\text { Methodology }\end{array}$ \\
\hline $\begin{array}{l}\text { Relative } \\
\text { importance } \\
\text { index (RII) }\end{array}$ & $R I I=\frac{\sum r}{A \times N}$ & $\begin{array}{l}\text { where } r=\text { rating given to each factor } \\
\text { by the respondents and ranges from } 1 \\
\text { to } 5 \text { where ' } 1 \text { ' is 'not significant' and ' } 5 \text { ' } \\
\text { is 'extremely significant', } \mathrm{A}=\text { highest } \\
\text { rating (i.e. } 5 \text { in this case), and } \mathrm{N}=\text { total } \\
\text { number of respondents. }\end{array}$ & $\begin{array}{l}\text { Ramanathan, et al. } \\
\text { (2012) }\end{array}$ & $\begin{array}{l}\text { Through } \\
\text { questionnaire } \\
\text { survey }\end{array}$ \\
\hline $\begin{array}{l}\text { Relative } \\
\text { importance } \\
\text { index (RII) }\end{array}$ & $I=\frac{\sum_{i=1}^{5} W_{i} X_{i}}{\sum_{i=1}^{5} X_{i}}$ & $\begin{array}{l}\text { Where } i=\text { response category index, Wi } \\
=\text { the weight assigned to the } i \text { th } \\
\text { response. } \mathrm{Xi}=\text { frequency of the } i \text { th } \\
\text { response given as percentage of the } \\
\text { total responses for each case. }\end{array}$ & $\begin{array}{l}\text { Odeh and Battaineh } \\
(2002)\end{array}$ & $\begin{array}{l}\text { Through } \\
\text { questionnaire } \\
\text { survey }\end{array}$ \\
\hline $\begin{array}{l}\text { Relative } \\
\text { importance } \\
\text { weight } \\
\text { (RIW) }\end{array}$ & $R I W=\frac{\sum_{i=1}^{5} a_{i} n_{i}}{\sum_{j=1}^{5} X_{j}} \times 1$ & $\begin{array}{l}\text { where: } x j=\text { the sum of the } j \text { th factor; } \\
\mathrm{j}=\text { the factors } 1,2,3,4, \ldots \mathrm{N} ; \mathrm{N}=\text { total } \\
\text { number of factors }(26) ; \text { ai }=\text { constant } \\
\text { expressing the weight given to the ith } \\
\text { response: } \mathrm{i}=1,2,3,4,5\end{array}$ & $\begin{array}{l}\text { Ramanathan, et al. } \\
\text { (2012) }\end{array}$ & $\begin{array}{l}\text { Through } \\
\text { questionnaire } \\
\text { survey }\end{array}$ \\
\hline $\begin{array}{l}\text { Importance } \\
\text { index (Ip.I) }\end{array}$ & $I p . I=\frac{\sum_{i=1}^{5} a_{i} x_{i}}{W .100}$ & $\begin{array}{l}\text { Where; } \mathrm{a}_{\mathrm{i}}=\text { constant expressing the } \mathrm{i}^{\text {th }} \\
\text { response, } \mathrm{x}_{\mathrm{i}}=\text { level of response given as } \\
\text { a } \% \text { of total responses, } \mathrm{i}=\text { response } \\
\text { category index, } \mathrm{W}=\text { highest weight }\end{array}$ & $\begin{array}{l}\text { Alwi and Hampson } \\
2003\end{array}$ & $\begin{array}{l}\text { Through } \\
\text { questionnaire } \\
\text { survey }\end{array}$ \\
\hline $\begin{array}{l}\text { Frequency } \\
\text { index }(\%) \\
\text { (F.I.) }\end{array}$ & $F . I .=\sum a(n / N) \rtimes$ & $\begin{array}{l}\text { a is the constant expressing weighting } \\
\text { given to each response (ranges from } 1 \\
\text { for rarely up to } 4 \text { for always), } \mathrm{n} \text { is the } \\
\text { frequency of the responses, and } \mathrm{N} \text { is } \\
\text { total number of responses. }\end{array}$ & \multirow{3}{*}{$\begin{array}{l}\text { Assaf and Hejji } \\
(2006)\end{array}$} & \multirow{3}{*}{$\begin{array}{l}\text { Through } \\
\text { questionnaire } \\
\text { survey }\end{array}$} \\
\hline $\begin{array}{l}\text { Severity } \\
\text { index }(\%) \\
\text { (S.I.) }\end{array}$ & S.I. $=\sum a(n / N) \times$ & $\begin{array}{l}\text { a is the constant expressing weighting } \\
\text { given to each response (ranges from } 1 \\
\text { for rarely up to } 4 \text { for always), } \mathrm{n} \text { is the } \\
\text { frequency of the responses, and } \mathrm{N} \text { is } \\
\text { total number of responses. }\end{array}$ & & \\
\hline $\begin{array}{l}\text { Importance } \\
\text { index }(\%) \\
\text { (IMP.I.) }\end{array}$ & $I M P . I=\frac{F . I . \times}{10}$ & & & \\
\hline $\begin{array}{l}\text { Relative } \\
\text { importance } \\
\text { index } \\
\text { (RII) }\end{array}$ & $R I I=\frac{\sum W}{A \times N}$ & $\begin{array}{l}\text { where } \mathrm{w}=\text { weighting given to each } \\
\text { factor by the respondents and ranges } \\
\text { from } 1 \text { to } 5 \text { where ' } 1 \text { ' is 'not significant' } \\
\text { and ' } 5 \text { ' is 'extremely significant', } \mathrm{A}= \\
\text { highest weight (i.e. } 5 \text { in this case), and } \\
\mathrm{N}=\text { total number of respondents. }\end{array}$ & $\begin{array}{l}\text { Sambasivan \& Soon } \\
2007\end{array}$ & $\begin{array}{l}\text { Through } \\
\text { questionnaire } \\
\text { survey }\end{array}$ \\
\hline
\end{tabular}

\begin{tabular}{|c|c|c|c|c|}
\hline $\begin{array}{l}\text { Analysis } \\
\text { methodology }\end{array}$ & Analytical formula & Parameters & $\begin{array}{l}\text { Referen } \\
\text { ce }\end{array}$ & $\begin{array}{l}\text { Research } \\
\text { Methodology }\end{array}$ \\
\hline $\begin{array}{l}\text { Mean score } \\
\text { (MS) }\end{array}$ & $M S=\left(4-\frac{\sum(f \times s)}{N}\right)$ & $\begin{array}{l}\text { Where MS is the mean score, ' } \mathrm{f} \text { ' is the } \\
\text { frequency of responses to each rating ( } 1 \text { - } \\
4 \text { ), s is the score given to each factor by } \\
\text { the respondents (ranges from } 1 \text { to } 4 \text { ), and } \\
\mathrm{N} \text { is the total number of responses } \\
\text { concerning that factor }\end{array}$ & $\begin{array}{l}\text { Alaghba } \\
\text { ri et al. } \\
(2007)\end{array}$ & $\begin{array}{l}\text { Through } \\
\text { questionnaire } \\
\text { survey }\end{array}$ \\
\hline $\begin{array}{l}\text { Overall mean } \\
\text { scores (OMS) }\end{array}$ & $O M S=\sum M S_{i j} \times \frac{N_{i}}{N_{1}+N_{2}+N_{3}}$ & $\begin{array}{l}\text { Where } \mathrm{i}=\text { Group } 1,2 \text { or } 3 \text { (client, } \\
\text { consultant, contractor group); } \mathrm{MS}=\text { mean } \\
\text { score; } \mathrm{Ni}=\text { number of respondents in each } \\
\text { group; and } \mathrm{j}=\mathrm{jth} \text { item in a group. }\end{array}$ & $\begin{array}{l}\text { Tommy } \\
\text { et al. } \\
(2006)\end{array}$ & $\begin{array}{l}\text { Through } \\
\text { questionnaire } \\
\text { survey }\end{array}$ \\
\hline $\begin{array}{l}\text { Frequency } \\
\text { index }(\%) \\
\text { (F.I.) }\end{array}$ & $F . I .=\frac{\sum_{i=0}^{4} a_{i} n_{i}}{4 N}$ & $\begin{array}{l}a=\text { constant expressing the weight } \\
\text { assigned to each responses (ranges from } \\
0 \text { for No happen to } 4 \text { for Always) } n= \\
\text { frequency of each response, } N=\text { total } \\
\text { number of responses. }\end{array}$ & \multirow{3}{*}{$\begin{array}{l}\text { Le-Hoai } \\
\text { et al. } \\
2008\end{array}$} & \multirow{3}{*}{$\begin{array}{l}\text { Through } \\
\text { questionnaire } \\
\text { survey }\end{array}$} \\
\hline $\begin{array}{l}\text { Severity index } \\
(\%) \\
\text { (S.I.) }\end{array}$ & $S . I .=\frac{\sum_{i=0}^{4} a_{i} n_{i}}{4 N}$ & $\begin{array}{l}a=\text { constant expressing the weight } \\
\text { assigned to each responses (ranges from } \\
0 \text { for No happen to } 4 \text { for Always), } n= \\
\text { frequency of each response, } N=\text { total } \\
\text { number of responses. }\end{array}$ & & \\
\hline $\begin{array}{l}\text { Relative } \\
\text { importance } \\
\text { index } \\
\text { (RII) }\end{array}$ & $I M P . I=F . I . \times S . I$. & & & \\
\hline
\end{tabular}




\section{Computerized SCHEdule delay ANALYSis Methods}

The occurrence of delay is common in most construction projects, due to various reasons and causes before or during construction phase. The delay analysis involves not only calculation of delay time but also identification of causes of occurrence. In construction research of delay analysis, researcher makes an effort to determine causes of delay(s) and remedial measures are performed in schedules to incorporate updated duration and new project time. Although many delay analysis methodologies have been discovered, but still the time consuming condition doesn't changed. This shows that the analysis itself involves complicated nature and it is necessary to simplified it by a computerized approach.

\section{AS-PLANNED AND AS-BUILT SCHEDULE DELAY ANALYSIS METHOD}

As-planned Method measures the contractor's planned or intended performance. Under this method the scope of the changed work is reviewed to determine where and how the revisions should be incorporated in the schedule. As-built schedule is basically the comparison of what was planned to what actually occurred, this method is also known as Traditional Method (Budshait and Cunningham, 1998).

\section{WHAT-IF AND BUT-FOR METHOD}

The what-if method accepts as-planned schedule as its baseline. In this method delay credited to one side is added to the as-planned schedule and resulted delay on project duration is calculated. Same process is performed for other side (Kim et al 2005).

The but-for method accepts as-built schedule as its baseline. This method subtracts the delay credited to the owner from the as-built schedule. The time difference between the as-built schedule and bu-for schedule is the compensable delay (Kim et al 2005).

\section{ISOLATED COLLAPSED BUT-FOR (ICBF) METHOD}

This method uses as-planned and as-built schedule to indentify delay events. The documents provided in file format and converting into a compatible format is very important to process a computerized analysis program. As built schedule reflects the actual project records of start and finish time of events. ICBF method uses the as-built schedule to determine the causes of schedule delays. This computerized program rapidly and schematically analyzes schedule delay, classifies delay liability and finds results (Yang et al. 2011).

\section{CONTEMPORANEOUS PERIOD ANALYSIS METHOD (CPA)}

The CPA method breaks the construction period into discrete time increments and examines the effects of the delays [11]. CPA method is also called as windows delay analysis method. This method breaks project into a no. of sequential periods called windows and analyses delays that occurred in each window successively [13].

Window analysis method is based on critical path method, which is consisting of scheduled activities and progress analysis. The analysis takes first as-planned schedule and contemporaneous site information showing as-built events from project start up to the end of respective window then each window is analyzed separately.

\section{CONCLUSION}

The critical review undertaken in this paper covers analytical and computerized schedule analysis methods for studying effect of construction delay factors. There are various methods suggested in literature that are acceptable for deciding the importance of delay factors. Each study has its analytical approach which gives unique results. These results are derived from questionnaire data. Various statistical methods like Rank Correlation Coefficient, Relative Importance Index (RII), Important Index, Frequency Index (FI), Severity Index (SI) and Mean Score (MS) have been determined to analyze the impact of delay factors on project performance. The delay analysis methodology presented in this study gives comparison of methods which are used in construction sector for computing impact of delay and the computerized approach helps to improve efficiency in maximizing project performance.

\section{REFERENCES}

[1] Aibinu, A. A., and Odeyinka, H. A. (2006). "Construction delays and their causative factors in Nigeria". J. Constr. Eng. and Mgmt., (ASCE), 132(7), 667-677.

[2] Alaghbari, W., Kadir, M.R.A., Salim, A., and Ernawati (2007) 'The significant factors causing delay of building construction projects in Malaysia', Engineering, Construction and Architectural Management, 14 (2), 192-206.

[3] Alwi, S., and Hampson, K. (2003). "Identifying the important causes of delays in building construction projects". The 9th East Asia-Pacific conference on structural eng. and constr., Bali, Indonesia.

[4] Assaf, S. A., Al-Khalif, M., and Al-Hazmi, M. (1995). "Causes of delay in large building construction projects". J. Mgmt. Eng., $11(2), 45-50$. 
[5] Assaf, S. A., and Al-hejji S. (2006). "Causes of delay in large construction projects". International J. Project Mgmt., Science Direct, $24,349-357$.

[6] Bubshait, A. A. and Cunningham, M. J. (1998). “Comparision of delay analysis methodologies". J. Constr. Eng. Mgmt., ASCE, 124(4), 315-322.

[7] Finke, M. R. (1999). "Window analysis of compensable delays". J. Constr. Eng. and Mgmt., ASCE, 125(2), 96-100.

[8] Haseeb, M., Xinhai-Lu, Bibi, A., Dyian, M., and Rabbani, W., (2011). "Problems of projects and effects of delays in the construction industry of Pakistan". Australian Journal of Business and Mgmt. Research, 1(5), 41-50.

[9] Hegazy, T., Zhang, K. (2005). "Daily windows delay analysis". J. Constr. Eng. and Mgmt., ASCE, $131(5), 505-512$.

[10] Jonathan, J. S., Cheung, S. D., David, A. (2001)."Construction delay computation method". Journal of Construction Engineering and Management, 127, 60-65.

[11] Kim, Y., Kim, K., and Shin, D. (2005). "Delays analysis method using delay section”. J. Constr. Eng. And Mgmt., ASCE, 131(11), 1155-1164.

[12] Le-Hoai, L., Lee, Y. D., and Lee, J. Y. (2008). "Delay and cost overruns in Vietnam large construction projects: A comparison with other selected countries". KSCE Journal of Civil Eng., 12(6), 367-377.

[13] Menesi, W. (2007). "Construction delay analysis under multiple baseline updates". A Thesis Report University of Waterloo, Canada MA, 2007.

[14] Odeh, A.M. and Battaineh H (2002). "Causes of construction delay: traditional contracts", International Journal of project Management, 20 (1), 67-73.

[15] Ramanathan, C., and Narayanan, S. P., and Idrus, A. B. (2012). "Construction delays causing risks on time and cost-a critical review". Australian J. Constr. Economics and Bldg., 12(1), 37-57.

[16] Sambasivan, M. and Soon, Y.W. (2007) 'Causes and effects of delays in Malaysian construction industry', International Journal of Project Management, 25 (5), 517-526.

[17] Tommy, Y., Fung, W. H., and Tung, C. F. (2006). "Construction delays in Hong Kong civil engineering projects”. J. Constr. Eng. and Mgmt., ASCE, 132(6), 636-649.

[18] Yang, J., Tsai, M., (2011). “Computerizing ICBF method for schedule delay analysis”. J. Constr. Eng. and Mgmt., ASCE, 137(8), 583-591. 